\title{
Front Matter: Volume 11204
}

, "Front Matter: Volume 11204," Proc. SPIE 11204, 14th Conference on Integrated Optics: Sensors, Sensing Structures, and Methods, 1120401 (13 September 2019); doi: 10.1117/12.2549347

SDIE Event: Fourteenth Integrated Optics-Sensors, Sensing Structures and SPIE. Methods Conference, 2019, Szcyrk-Gliwice, Poland 


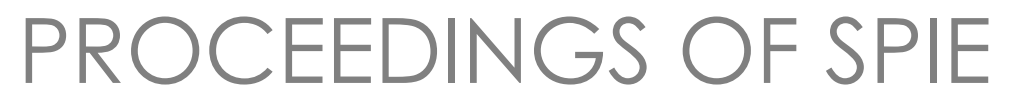

\section{4th Conference on Integrated Optics: Sensors, Sensing Structures, and Methods}

Przemyslaw Struk

Tadeusz Pustelny

Editors

25 February-1 March 2019

Szcyzyrk, Poland

Cosponsored by

Committee of Electronics and Telecommunication, Polish Academy of Sciences (Poland)

Technical Organizers

Photonics Society of Poland (Poland)

Polish Acoustical Society, Upper Silesian Division (Poland)

Published by

SPIE

Volume 11204 
The papers in this volume were part of the technical conference cited on the cover and title page. Papers were selected and subject to review by the editors and conference program committee. Some conference presentations may not be available for publication. Additional papers and presentation recordings may be available online in the SPIE Digital Library at SPIEDigitalLibrary.org.

The papers reflect the work and thoughts of the authors and are published herein as submitted. The publisher is not responsible for the validity of the information or for any outcomes resulting from reliance thereon.

Please use the following format to cite material from these proceedings:

Author(s), "Title of Paper," in 14th Conference on Integrated Optics: Sensors, Sensing Structures, and Methods, edited by Przemyslaw Struk, Tadeusz Pustelny, Proceedings of SPIE Vol. 11204 (SPIE, Bellingham, WA, 2019) Seven-digit Article CID Number.

ISSN: 0277-786X

ISSN: 1996-756X (electronic)

ISBN: 9781510631502

ISBN: 9781510631519 (electronic)

Published by

SPIE

P.O. Box 10, Bellingham, Washington 98227-0010 USA

Telephone +13606763290 (Pacific Time) · Fax +1 3606471445

SPIE.org

Copyright @ 2019, Society of Photo-Optical Instrumentation Engineers.

Copying of material in this book for internal or personal use, or for the internal or personal use of specific clients, beyond the fair use provisions granted by the U.S. Copyright Law is authorized by SPIE subject to payment of copying fees. The Transactional Reporting Service base fee for this volume is $\$ 21.00$ per article (or portion thereof), which should be paid directly to the Copyright Clearance Center (CCC), 222 Rosewood Drive, Danvers, MA 01923. Payment may also be made electronically through CCC Online at copyright.com. Other copying for republication, resale, advertising or promotion, or any form of systematic or multiple reproduction of any material in this book is prohibited except with permission in writing from the publisher. The CCC fee code is 0277$786 \times / 19 / \$ 21.00$.

Printed in the United States of America by Curran Associates, Inc., under license from SPIE.

Publication of record for individual papers is online in the SPIE Digital Library.

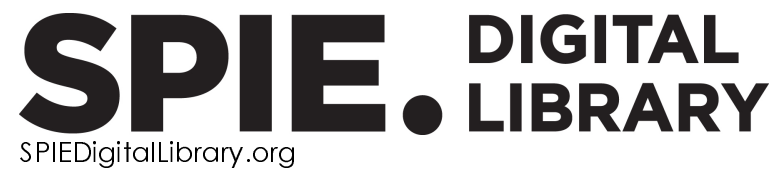

Paper Numbering: Proceedings of SPIE follow an e-First publication model. A unique citation identifier (CID) number is assigned to each article at the time of publication. Utilization of CIDs allows articles to be fully citable as soon as they are published online, and connects the same identifier to all online and print versions of the publication. SPIE uses a seven-digit CID article numbering system structured as follows:

- The first five digits correspond to the SPIE volume number.

- The last two digits indicate publication order within the volume using a Base 36 numbering system employing both numerals and letters. These two-number sets start with $00,01,02,03,04$, 05, 06, 07, 08, 09, OA, OB ... 0Z, followed by 10-1Z, 20-2Z, etc. The CID Number appears on each page of the manuscript. 


\title{
Contents
}

\author{
V $\quad$ Authors \\ vii Conference Committees \\ ix Introduction
}

14TH CONFERENCE ON INTEGRATED OPTICS: SENSORS, SENSING STRUCTURES, AND METHODS

1120402 Design of an integrated optics sensor structure for hemoglobin property detection [11204-2]

$1120403 \quad$ Vision sensor for measuring liquid volume [1 1204-3]

$1120404 \quad$ Evaluation of the impact of evolution strategy parameters on the optimization of the markers distribution on the VAD membrane [1 $11204-4]$

1120405 Determination of gas pressure with use of a digital camera and neural networks [11204-5]

1120406 Analysis of optical magnetic field sensor in wide range of wavelengths [1 $1204-6]$

$1120407 \quad$ Application of machine learning methods in provisioning of DWDM channels [1 1204-8]

1120408 The output signal of the broadband differential interferometer as a function of the thickness of the single-mode optical waveguide [1 $11204-9]$

1120409 Silk fibroin thin films for optical humidity sensing [1 1204-10]

11204 OA Identification of optical signatures for the augmented reality system [1 $1204-11$ ]

11204 OB Thermographic analysis of power oil transformer surface hot spot areas combined with analysis of acoustic signals recorded on line [11204-12]

11204 OC Simulation tool to check correctness of optical signatures detection [1 1204-13]

11204 OD Application of evolutionary algorithm to optimization of DWDM networks [1 $1204-14]$

$11204 \mathrm{OE} \quad$ Growth and preliminary characterization of InAsSb photodiodes for mid-wave infrared detection [1 1 1204-15]

11204 OF On the nonlinear dynamics of coupled micro-resonators [1 1204-17] 
11204 OG Objects tracking in virtual reality applications using SteamVR tracking system: selected issues [11204-19]

$11204 \mathrm{OH} \quad$ The sensitivity of reduced graphene oxide to $\mathrm{H}_{2}$ and $\mathrm{NO}_{2}$ [1 1 204-20]

11204 Ol Study on feature analysis used for designing hand-held retina vessels extraction sensor [11204-21]

11204 OJ The use of laser printers for obtaining photomasks for the photolithography process [1 1204-23]

11204 OK Investigation of room temperature optical gas sensing properties of chitosan [1 1204-24]

$11204 \mathrm{OL} \quad$ Influence of near UV radiation on organic thin film transistor based on conductive polymer and ZnO thin films blend [1 1204-25] 


\section{Authors}

Numbers in the index correspond to the last two digits of the seven-digit citation identifier (CID) article numbering system used in Proceedings of SPIE. The first five digits reflect the volume number. Base 36 numbering is employed for the last two digits and indicates the order of articles within the volume. Numbers start with 00, 01, 02, 03, 04, 05, 06, 07, 08, 09, OA, OB...0Z, followed by 10-12, 20-2Z, etc.

Arciuch, Artur, OA, OC

Aznar-Cervantes, Salvador D., 09

Barczak, Kamil, 06

Buler, Piotr Adam, Ol

Dinh, Xuan Khoa, OF

Domínguez Horna, Carlos, 09

Drewniak, Sabina, $\mathrm{OH}$

Grad, Leszek, 04, 05

Gut, Kazimierz, 08, 0J

Kałużyński, P., OL

Kozdrowski, Stanisław, 07, OD

Kubiszyn, Łukasz, OE

Le, Xuan The Tai, OF

Lipski, Kordian, $\mathrm{OE}$

Lisowska-Lis, Agnieszka, OB

Luis Cenis, Jose, 09

Maciak, Erwin, OK

Maciejewski, Marcin, 0G

Malinowski, Tomasz, 04, 05

Márquez Maqueda, Augusto, 09

Martyniuk, Piotr, OE

Michalczewski, Krystian, OE

Muñoz Berbel, Xavier, 09

Murawska, Monika, 03

Murawski, Krzysztof, 03, 0l

Murawski, Krzysztof, OE

Nguyen, Duy Cuong, OF

Nguyen, Viet Hung, OF

Opilski, Zbigniew, 09

Pałka, Norbert, OG

Pałys, Tomasz, OA, OC

Paziewski, Piotr, 07

Piszczek, Marek, OG

Pomianek, Mateusz, OG

Procek, Marcin, 09, OH, OL

Sikorski, Arkadiusz, OD

Stolarczyk, Agnieszka, OL

Struk, Przemysław, 02

Student, Sebastian, OJ

Sujecki, Sławomir, 07, OD

Szerszen, Grzegorz, OB

Trippenbach, Marek, OF

Witos, Franciszek, OB

Wnuk, Kacper, OD 
Proc. of SPIE Vol. 11204 1120401-6

\section{Downloaded From: https://www.spiedigitallibrary.org/conference-proceedings-of-spie on 26 Apr 2023
Terms of Use: https://www.spiedigitallibrary.org/terms-of-use}




\title{
Conference Committees
}

\author{
Conference Chair \\ Tadeusz Pustelny, Silesian University of Technology, Gliwice (Poland) \\ Honorary Conference Chair
}

Wiesław L. Woliński, Warsaw University of Technology (Poland)

Scientific Committee

Tadeusz Pustelny, Chairman, Silesian University of Technology, Gliwice (Poland)

Tomasz R. Woliński, Vice-Chairman, Warsaw University of Technology, (Poland)

Zbigniew Bielecki, Military University of Technology (Poland)

Marek Blahut, Silesian University of Technology (Poland)

Dominik Dorosz, AGH University of Science and Technology (Poland)

Jan Jakubczyk, Optiwave Systems, Inc. (Canada)

Leszek Jaroszewicz, Military University of Technology (Poland)

Malgorzata Jedrzejewska-Szczerska, Gdansk University of Technology (Poland)

Przemyslaw Struk, Silesian University of Technology (Poland)

Erwin Maciak, Silesian University of Technology (Poland)

Miroslaw Karpierz, Warsaw University of Technology (Poland)

Wieslaw Królikowski, University of Canberra (Australia)

Pawel Mergo, Maria Curie-Sklodowska University (Poland)

Krzysztof Murawski, Military University of Technology (Poland)

Andrzej Napieralski, Lodz University of Technology (Poland)

Risto A. Myllylä, University of Oulu (Finland)

Mieczysław Szustakowski, Military University of Technology (Poland)

Jacek Wojtas, Military University of Technology (Poland)

\section{Organizing Committee}

Tadeusz Pustelny, Silesian University of Technology, Gliwice (Poland) Przemyslaw Struk, Silesian University of Technology, Gliwice (Poland) Aneta Olszewska, Silesian University of Technology, Gliwice (Poland) Marcin Procek, Silesian University of Technology, Gliwice (Poland) Kamil Barczak, Silesian University of Technology, Gliwice (Poland) Sabina Drewniak, Silesian University of Technology, Gliwice (Poland) 
Proc. of SPIE Vol. 11204 1120401-8 Downloaded From: https://www.spiedigitallibrary.org/conference-proceedings-of-spie on 26 Apr 2023
Terms of Use: https://www.spiedigitallibrary.org/terms-of-use 


\section{Introduction}

The 14th Conference on Integrated Optics: Sensors, Sensing Structures, and Methods is the international scientific forum of photonics and modern nanotechnology.

The Integrated Optics (IOS) conference is organized every year since 2004, and in 2019 it was held for the fourteenth time.

IOS 19 took place from 25 February to 1 March 2019 in Szczyrk, Poland, in the META Hotel in the Beskidy Mountains in southern Poland in a real wintery scene.

IOS 19 was attended by 65 scientists, mainly from Poland, as well as presenters from France, Spain, Australia, Qatar, and the Czech Republic.

The main organizer of the 14th Conference on Integrated Optics: Sensors, Sensing Structures, and Methods was the Photonics Society of Poland in cooperation with SPIE. The technical organizers of the conference were the Upper Silesian Division of the Polish Acoustical Society and the Optoelectronic Department at the Silesian University of Technology in Gliwice (Poland).

The Honorary patronage of the Conference has been taken over by Professor Wieslaw Wolinski - Full Member of the Polish Academy of Sciences.

During IOS19 thirty-four oral lectures were held in 8 scientific sessions. In addition, twenty eight posters were presented during the poster session.

The main aim of IOS19 was an exchange of knowledge in the scope of practical applications of photonics, integrated optics, and related scientific areas. The objectives of the conference were accomplished in presentations of experiences in the field of technology and theoretical analysis of optoelectronic sensors and practical applications of sensing structures and systems, as well as on new methods in the field of modern metrology.

IOS19 has contributed to the extension of relations between scientific groups and has enabled the intensification of common cooperation for the development of photonics and integrated optics.

Tadeusz Pustelny 
Proc. of SPIE Vol. 11204 1120401-10 Downloaded From: https://www.spiedigitallibrary.org/conference-proceedings-of-spie on 26 Apr 2023
Terms of Use: https://www.spiedigitallibrary.org/terms-of-use 